\title{
The viability of Phanerochaete chrysosporium inoculant in gamma-irradiated-compost carrier and its biosorption efficiencies for Cd (II) and $\mathrm{Cr}$ (VI)
}

\author{
Megga Ratnasari Pikoli ${ }^{a, *}$, Ida Farida ${ }^{b}$, Tri Retno Dyah Larasatic, and Nana Mulyana ${ }^{\mathrm{d}}$ \\ ${ }^{\mathrm{a}, \mathrm{b}}$ Department of Biology, Faculty of Science and Technology \\ Syarif Hidayatullah State Islamic University (UIN) Jakarta, Indonesia \\ ${ }^{\mathrm{c}, \mathrm{d}}$ Pusat Aplikasi Isotop dan Radiasi \\ National Nuclear Energy Agency (BATAN) Jakarta, Indonesia \\ *Email : meggapikoli@uinjkt.ac.id
}

\begin{abstract}
Phanerochaete chrysosporium is a well-known fungus that can be used as a heavy metal biosorbent. Its application as an inoculant requires a suitable carrier material. This study aims to obtain formula of solid carrier material which maintains the viability and quality of this fungus as biosorbent of $\mathrm{Cd}$ (II) and $\mathrm{Cr}$ (VI). The carrier bases are carboxymethyl cellulose and talk, which are then varied by the addition of compost and charcoal husk. The carriers were treated by gamma-irradiation of $25 \mathrm{kGy}$ and autoclaved by $121{ }^{\circ} \mathrm{C}$, and examined after 28 days of storage. The data were analyzed by analysis of variance with $95 \%$ level of significance. The results showed that gamma-irradiation was able to sterilize the carrier until the microorganism was not detected anymore, without altering its characteristics significantly, while microbial growth was found from those sterilized by the autoclave. The carrier can significantly maintain the viability of the fungus for 28 days. The highest biosorption efficiency of Cd occurred in the treatment with the addition of compost alone, i.e. $84 \%$ by irradiation and $86 \%$ by autoclave sterilization. Similarly, the highest biosorption efficiency of $\mathrm{Cr}$ occurred in the treatment with the addition of compost alone, i.e. $70 \%$ by irradiation and $69 \%$ by autoclave, as well as $72 \%$ with the addition of irradiated compost and charcoal husk. It was concluded that P. chrysosporium in the irradiated carrier is able to maintain its viability and absorb $\mathrm{Cd}$ (II) and $\mathrm{Cr}$ (VI) efficiently.
\end{abstract}

Keywords: Phanerochaete chrysosporium, Biosorption, Inoculant carrier, Cadmium, Chromium

\section{Introduction}

Phanerochaete chrysosporium has been known for its ability to absorb various heavy metals. The removal efficiencies of its biomass for cadmium reached $63.62 \%$, under the optimum conditions [1]. The fungi also showed the removal of $99.7 \%$ chromium from fortified solutions detected spectrophotometrically after $72 \mathrm{hrs}$ [2]. The mechanisms of biosorption by the fungal biomass involve cell-surface sorption, intracellular accumulation, or precipitation/ extracellular accumulation [3]. Its effectiveness in absorbing heavy metals is supported by inexpensive cost and environmentally friendly technology, so the biosorption by these fungi can be utilized in bioremediation of heavy metals from soil and water bodies.

Fungi as bioremediation agents are usually inoculated along with carrier materials, which aims to facilitate field use and to maintain viability over a period of time. The biomass in the carrier is immobilized to improve microorganisms' resistance to unfavorable environmental impacts. A good carrier should be insoluble, non-toxic, both for the immobilized material and the environment, easily accessible, inexpensive, stable and suitable for regeneration [4]. Compost as a carrier has been used in biofertilizer applications, for example by using agents of rhizobial bacteria [5] dan arbuscular mycorrhizal fungi [6].

Sterilization of carrier material is a step that must be done for the purpose so that the carrier material is not damaged by contaminants. The carrier damage is not expected because it affects the viability of the inoculants. The sterilized carrier can maintain the high number of inoculant microorganisms in long storage periods. Sterilization by heating can use an autoclave that utilizes heat in a pressurized chamber with a temperature of $121^{\circ} \mathrm{C}$ for 60 minutes. However, autoclave sterilization causes some materials to change their properties and produce a toxic substance to some bacterial strains [7]. Another sterilization method is gamma irradiation $[5,7,8]$, which has the advantage of not changing the carrier characteristics. The $25 \mathrm{kGy}$ dosage has been widely used for sterilization of compost-based carriers capable of killing microorganisms both bacteria and fungi [9]. Therefore, this study was conducted to determine the ability of carrier substances sterilized by autoclave and irradiated gamma with a dose of $25 \mathrm{kGy}$ in maintaining $P$. chrysosporium viability. The $P$. chrysosporium containing carrier is then applied to metal biosorption of Cd (II) and Cr (VI).

\section{Methods}

\section{A. Experimental Design, Preparation of Carriers and} Their Sterilization

The experiments consisted of four variations in the carrier composition, which were then sterilized with 
gamma-irradiation or autoclaving (Table 1). All ingredients, i.e. compost (50 g), charcoal husk (50 g), carboxyl methyl cellulose (CMC) (200 g) and talc (200 mg) were oven-dried at $70^{\circ} \mathrm{C}$ for 72 hours and mashed to $<200$ $\mathrm{mm}$ in particle size.

Ten percent $(\mathrm{v} / \mathrm{b})$ of a mineral salt solution was added into each carrier, that each liter consisting of $\left(\mathrm{NH}_{4}\right)_{2} \mathrm{SO}_{4} 1$ $\mathrm{g}, \mathrm{KH}_{2} \mathrm{PO}_{4} \quad 0.5 \mathrm{~g}$ and $\mathrm{MgSO}_{4} .7 \mathrm{H}_{2} \mathrm{O} \quad 0.2 \mathrm{~g}$ [10], supplemented with nutrients of molasses $50 \mathrm{~g}$, tryptic soy broth $30 \mathrm{~g}$, and potato dextrose broth $24 \mathrm{~g}$. Two grams of the carrier was fed into polyethylene bags, and sterilized with gamma irradiation at the dosage of $25 \mathrm{kGray}$ and autoclave at $121^{\circ} \mathrm{C}$ for $60 \mathrm{~min}$, according to the treatment (Table 1). Each set is in triplicate. The CMC was added as a stabilizer, whereas the talcum is a clay mineral composed of hydrated magnesium silicate $\left(\mathrm{H}_{2} \mathrm{Mg}_{3}\left(\mathrm{SiO}_{3}\right)_{4}\right.$ or $\left.\mathrm{Mg}_{3} \mathrm{Si}_{4} \mathrm{O}_{10}(\mathrm{OH})_{2}\right)$, as a coating agent.

Table 1. The treatments and their codes in this research

\begin{tabular}{|l|l|c|c|}
\hline \multicolumn{2}{|c|}{ Composition of carriers } & $\begin{array}{c}\text { Gamma- } \\
\text { Irradiation }(\boldsymbol{G})\end{array}$ & $\begin{array}{c}\text { Autoclaving } \\
(\boldsymbol{U})\end{array}$ \\
\hline $\mathrm{A}$ & $\mathrm{CMC}+$ talcum powder $(3: 1)$ & $\mathrm{AG}$ & $\mathrm{AU}$ \\
\hline $\mathrm{B}$ & $\begin{array}{l}\text { CMC + talcum powder + compost } \\
(2: 1: 1)\end{array}$ & $\mathrm{BG}$ & $\mathrm{BU}$ \\
\hline C & $\begin{array}{l}\text { CMC + talcum powder + charcoal } \\
\text { husk }(2: 1: 1)\end{array}$ & $\mathrm{CG}$ & $\mathrm{CU}$ \\
\hline D & $\begin{array}{l}\text { CMC + talcum powder }+ \text { compost } \\
+ \text { charcoal husk }(1: 1: 1: 1)\end{array}$ & $\mathrm{DG}$ & $\mathrm{DU}$ \\
\hline
\end{tabular}

\section{B. Assessment of the Characteristics of the Carriers}

The assessment aims to determine the carrier formulas that can maintain the viability of microorganisms. After sterilization, each of the carrier combination is measured for $\mathrm{pH}$, moisture content, organic matter, ash content, organic carbon and total nitrogen, by using standard methods commonly used for fertilizers.

\section{Assessment of Microorganisms after Sterilization}

Total microorganisms in the sterilized carrier were assessed by total plate count method preceded by dilution of 10 in a series of $0.85 \% \mathrm{NaCl}$ sterile solution. A total of $0.1 \mathrm{ml}$ of the dilution solution was inoculated onto tryptic soy agar plate and potato dextrose agar plate then incubated for 2 days at $37^{\circ} \mathrm{C}$. The bacterial colonies and fungi grown per $\mathrm{g}$ of carrier material were calculated.

\section{Preparation of Inoculant and its Storage}

About a 1-2 loop of $P$. chrysosporium culture was put into $25 \mathrm{ml}$ of potato dextrose broth and incubated in a shaker at $100 \mathrm{rpm}$ for 4 days. A total of $1 \mathrm{ml}(1.27 \times 107$ cells $/ \mathrm{ml}$ ) of the liquid culture was mixed with $2 \mathrm{~g}$ of the sterilized carrier material. The inoculant was incubated at room temperature. After being stored for 28 days, the viability of $P$. chrysosporium was examined by total plate count method on potato dextrose agar plate.

\section{E. Examination on Biosorption of Cd (II) and Cr (VI)}

The ability of $P$. chrysosporium inoculant as heavy metal biosorbent was evaluated in a liquid medium containing sterilized $40 \mathrm{ml}$ potato dextrose broth, $50 \mathrm{ppm}$ $\mathrm{CdSO}_{4}$ and $50 \mathrm{ppm} \mathrm{K}_{2} \mathrm{CrO}_{7}$. A total of $2 \mathrm{~g}$ of inoculant was inoculated into the liquid medium and incubated in a shaker at $100 \mathrm{rpm}$ and room temperature for 3 days, then proceed to measure medium $\mathrm{pH}$ and the biosorption examination. In the biosorption examination, the culture was separated from the medium by centrifugating at $12,000 \mathrm{rpm}$ for 15 minutes. A total of $5 \mathrm{ml}$ of supernatant was transferred into a digest tube and added with $5 \mathrm{ml}$ of concentrated nitric acid and $1 \mathrm{ml}$ of concentrated perchloric acid. The sample was destructed for 1 hour (up to white steam). The resulting destruction is cooled, then diluted with $10 \mathrm{ml}$ of aquadest and homogenized by gently shaking. Ten $\mathrm{ml}$ of sample was measured for $\mathrm{Cd}$ (II) and Cr (VI) by using an atomic absorption spectroscopy at wavelength 228.8 and $357.9 \mathrm{~nm}$. The ability of microorganisms to absorb heavy metals is identified from the decrease in metal concentrations in metal-containing media, compared with those without microorganisms as a control.

\section{F. Data Analysis}

The characteristics of the carrier were compared to meet the standard quality of carrier material of organic fertilizer according to the regulation of Ministry of Agriculture Republic of Indonesia [11] and the National Standardization Agency of Indonesia (Badan Standardisasi Nasional, BSN) [12]. Data on the viability of $P$. chrysosporium in the carrier and residual concentration of $\mathrm{Cd}$ (II) and $\mathrm{Cr}$ (VI) in media were analyzed by using analysis of variance $(p<0,05)$. Data showing significant difference among the treatments were then analyzed with Tukey's test. All the statistical data processing were performed by using Minitab16 [13].

\section{Result and Discussion}

\section{A. Characteristics of the Carriers}

Characteristics of the carriers were examined to determine the carrier formulas that can maintain the survival of $P$. chrysosporium (Table 2). Sterilization resulted in slight changes in some of these characteristics. The $\mathrm{pH}$ of the carrier ranges from 5 to 6 which is included in the range of $P$. chrysosporium viable cells to absorb metals (Table 2). Sterilization resulted in slight changes in some of these characteristics. The $\mathrm{pH}$ of the carrier ranges from 5 to 6 which is included in the range of $P$. chrysosporium viable cells to absorb metals [2]. The water content range of the carrier was $10-21 \%$, which is considered capable of maintaining the viability of $P$. chrysosporium if it is stored for longer periods, in accordance with the standard [11]. The organic materials in the carrier range from $50-70 \%$, which is considerably above the standard [12], which is mainly contributed by the high organic content in CMC, compost and charcoal husk. Organic carbon and total nitrogen are important components that are used as energy sources by microorganisms. Sterilization of the carrier, whether gamma-irradiated or autoclave does not change the organic carbon and total nitrogen significantly and still meets the standards. Generally, the characteristics of the sterilized carrier indicate that the carrier may be used by $P$. chrysosporium as a source of nutrients for a 28-day storage period. 
Table 2. Characteristics of the various carriers

\begin{tabular}{|c|c|c|c|c|c|}
\hline Carriers & $\boldsymbol{p H}$ & $\begin{array}{c}\text { Water } \\
\text { content } \\
(\%)\end{array}$ & $\begin{array}{c}\text { Organic } \\
\text { material } \\
(\%)\end{array}$ & $\begin{array}{c}\text { Organic } \\
\text { carbon } \\
(\%)\end{array}$ & $\begin{array}{c}\text { Total } \\
\text { nitrogen } \\
(\%)\end{array}$ \\
\hline A $^{*}$ & 5.7 & 16.91 & 72.65 & 10.84 & 0.13 \\
\hline B $^{*}$ & 6.14 & 12.93 & 56.68 & 10.00 & 0.55 \\
\hline C $^{*}$ & 5.81 & 10.8 & 76.52 & 9.142 & 0.33 \\
\hline $\mathbf{D}^{*}$ & 5.12 & 10.88 & 57.78 & 9.753 & 0.41 \\
\hline AG & 5.8 & 19.32 & 72.96 & 8.77 & 0.12 \\
\hline BG & 5.04 & 19.35 & 60.88 & 9.56 & 0.55 \\
\hline CG & 5.42 & 18.27 & 62.96 & 8.82 & 0.33 \\
\hline DG & 5.49 & 17.26 & 61.92 & 10.26 & 0.41 \\
\hline AU & 6.3 & 21.4 & 72.57 & 10.05 & 0.12 \\
\hline BU & 6.36 & 19.46 & 59.90 & 10.00 & 0.54 \\
\hline CU & 6.17 & 17.99 & 62.45 & 9.91 & 0.33 \\
\hline DU & 6.12 & 17.24 & 61.80 & 9.86 & 0.42 \\
\hline Standard & $4-8[11]$ & $>12[11]$ & $27-58[12]$ & $8-12[11]$ & $<6[11]$ \\
\hline
\end{tabular}

${ }^{*} \mathrm{~A}, \mathrm{~B}, \mathrm{C}, \mathrm{D}=$ carriers before sterilization

\section{B. Elimination of Microorganisms After Sterilization}

Examination of microorganisms in sterilized carriers showed that gamma irradiation sterilization was more effective than autoclave sterilization in suppressing the growth of microorganisms (Table 3). The gammairradiation sterilization method at a dose of $25 \mathrm{kGy}$ is able to sterilize the carrier material until the microorganism is not detected. Gamma ray is an effective method for sterilization, since the ionizing radiation interacts directly with charged particles such as DNA, and results in doublestrand break [5]. In contrast to sterilization with gammairradiation, autoclave sterilization left microorganisms, especially bacteria, with different concentrations according to the carrier composition. This showed that the heat from water vapor by an autoclave unable to penetrate the carrier matrix and thus unable to eliminate bacterial growth. This also occurred in another study which employed autoclaving with tyndallization approach on peat and compost [5]. However, different results occurred in the carrier in the form of peat moss, the mixture of peat moss plus vermiculite, wheat bran, rice husk, clay, and sodium alginate, sterilized by autoclave as well, that no contaminants have been detected in all the sterilized carriers[14]. Those means that the composition of the carrier material greatly determines the success of autoclave sterilization in eliminating contaminant microorganisms.

Table 3. The concentration of microorganisms in the carrier after sterilization

\begin{tabular}{|c|c|c|c|c|c|c|c|c|}
\hline \multirow{2}{*}{ Parameters } & \multicolumn{7}{|c|}{ Carriers and their sterilization methods } \\
\cline { 2 - 9 } & \multicolumn{6}{|c|}{ Gamma-irradiation } & \multicolumn{4}{c|}{ Autoclaving } \\
\cline { 2 - 9 } & $\boldsymbol{A G}$ & $\boldsymbol{B} \boldsymbol{G}$ & $\boldsymbol{C G}$ & $\boldsymbol{D G}$ & $\boldsymbol{A U}$ & $\boldsymbol{B U}$ & $\boldsymbol{C U}$ & $\boldsymbol{D U}$ \\
\hline $\begin{array}{c}\text { Bacteria } \\
(\boldsymbol{C F U} / \boldsymbol{g})\end{array}$ & 0 & 0 & 0 & 0 & $2,53 \times 10^{3}$ & $6,21 \times 10^{3}$ & $1,22 \times 10^{1}$ & $5,50 \times 10^{2}$ \\
\hline $\begin{array}{c}\text { Fungi } \\
(\boldsymbol{C F U} / \mathrm{g})\end{array}$ & 0 & 0 & 0 & 0 & 0 & 0 & 0 & $3,14 \times 10^{2}$ \\
\hline
\end{tabular}

\section{Viability of P. chrysosporium}

The examination of the viability of $P$. chrysosporium aims to determine the ability of $P$. chrysosporium to be maintained for a 28-day storage period in a sterilized carrier (Fig. 1). The fungal viability was significantly different $((p<0,05)$ among the treatments after 28 days of storage. The lowest viability of $P$. chrysosporium occurred on the sterilized CMC + talk carrier treatment with $25 \mathrm{kGy}$ (AG) gamma irradiation and autoclave sterilization (AU). In contrast, the treatments with the addition of compost and charcoal (BG, CG, DG, BU, CU, and DU) showed higher fungal viability than those without the addition of compost and charcoal husk (AG and AU). The high viability of $P$. chrysosporium in those carriers is expected because the compost carrier and charcoal husk contain cellulose, hemicellulose, and lignin that be fermented by $P$. chrysosporium [10]. The carrier, either sterilized with gamma-irradiation or autoclave, can significantly maintain the viability of the fungus for 28 days.

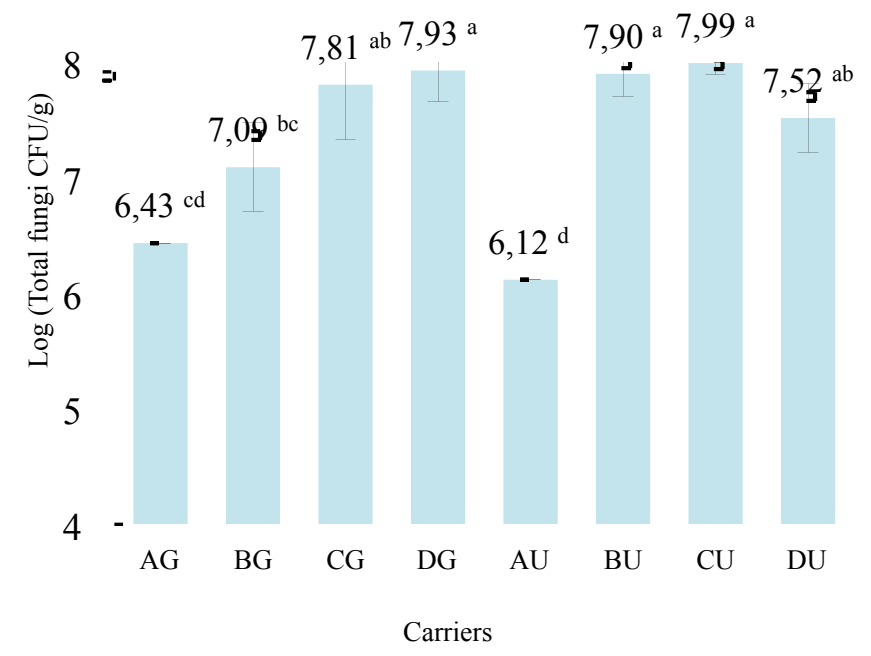

Fig. 1 The viability of $\mathrm{P}$. chrysporium in various sterilized carriers ) after 28 days of storage $(A=C M C+$ talc; $B=C M C+$ talc + compost $; \quad C=$ $C M C+$ talc + charcoal husk; $D=C M C+$ talc + compost + charcoal husk. The same letters on the bars show no difference significantly, $p<0.05$ )

\section{Biosorption efficiencies for $\mathrm{Cd}$ (II) and $\mathrm{Cr}$ (VI)}

The uptake of $\mathrm{Cd}$ (II) and Cr (VI) was separately significantly different $(p<0.05)$ among all the treatments, which the highest Cd (II) absorption efficiency was found in $\mathrm{BG}(84 \%)$ and $\mathrm{BU}(86 \%)$ (Fig. 2.A). This value is greater when compared with biosorption by $P$. chrysosporium while degrading 2,4-dichlorophenol [1]. The biosorption efficiency is also higher when compared with $P$. chrysosporium immobilized by growing onto polyurethane foam material in individual packed bed columns of $43 \%$ [15]. This is related to the formulation of the BG and BU carriers, of which composed of $50 \%$ compost. Compost from straw provides a living place and nutrients for the fungi because it contains lignocellulose that corresponds to the slow growth of the white rot fungi using its degradation enzymes. The next highest absorption efficiency of $\mathrm{Cd}$ (II) is DG, followed by DU. Both treatments of DG and DU contain compost, but with a smaller proportion than in BG and BU because the proportions are taken over by the charcoal content. The metal absorption is not only performed by the variety of functional groups on the fungal cell wall [3]. Charcoal has also a functional group that can attract metal ions, for 
example $-\mathrm{COO}^{-}$, which favors the adsorption of $\mathrm{Cd}^{2+}$ [16].

A

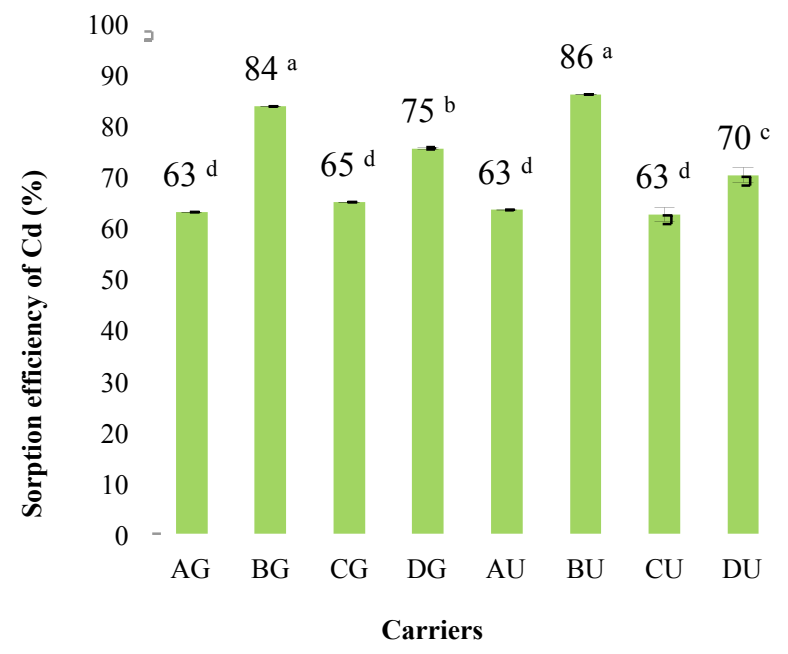

B

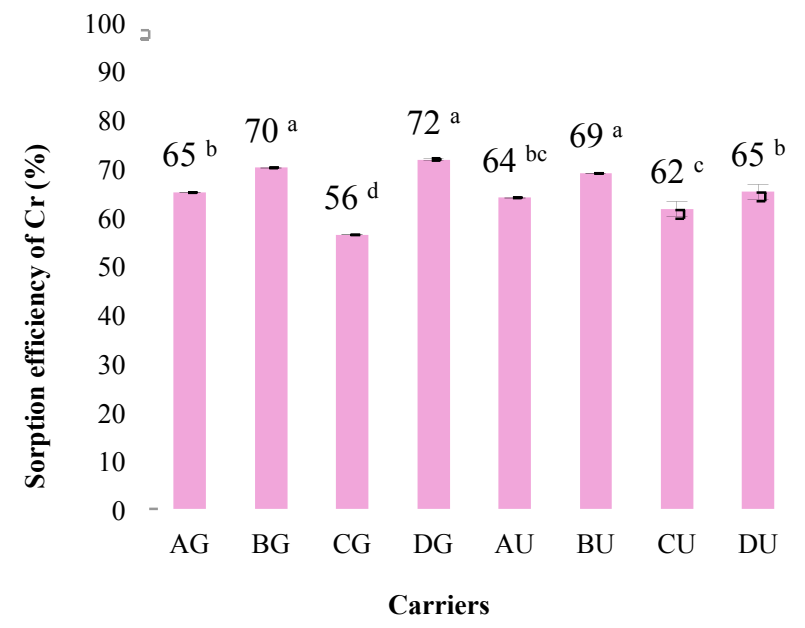

Fig 2. Biosorption efficiencies for Cd (II) (A) and Cr (VI) (B) after 28 days of storage. $(A=C M C+$ talc; $B=C M C+$ talc + compost; $C=C M C$ + talc + charcoal husk; $D=C M C+$ talc + compost + charcoal husk. The same letters on the bars show no difference significantly, $p<0.05$ )

Meanwhile, the highest $\mathrm{Cr}$ (VI) absorption efficiency was found in treatments of BG (70\%), DG (72\%) and BU (69\%) (Fig. 2.B). The percentage of absorption efficiency that around $70 \mathrm{~s} \%$ of the liquid medium containing $50 \mathrm{ppm}$ $\mathrm{Cr}$ (VI) was lower than the percentage removal of chromium from fortified solution $(100 \mathrm{ppm})$ by $P$. chrysosporium MTCC787 [2]. However, the compost content of the carrier for $P$. chrysosporium in the current research ensures the survival of the fungus.The carrier serves to protect and prevent the spread of organic pollutants and in this way reduces the surface contaminants concentration on the immobilized microorganisms [4]. In general, the results presented here show that the compost-containing carrier is the most suitable carrier for $P$. chrysosporium inoculants as biosorbent of Cd (II) and $\mathrm{Cr}$ (VI).

\section{Conclusion}

Sterilization by gamma-irradiation is better than autoclaving in terms of eliminating microorganisms in the carrier and capable of maintaining its characteristics. The most efficient chromium and cadmium sorption by the $P$. chrysosporium were mostly obtained from the compostcontaining materials, either sterilized by gamma-irradiation of autoclaving.

\section{References}

[1] A. Chen, G. Zeng, and G. Chen, "Simultaneous cadmium removal and 2,4-dichlorophenol degradation from aqueous solutions by Phanerochaete chrysosporium," Appl Microbiol Biotechnol, vol. 91, pp. 811-821, 2011.

[2] S. Pal and Y. Vimala, "Bioremediation of chromium from fortified solutions by Phanerochaete chrysosporium (MTCC 787)," J. Bioremediation Biodegrad., vol. 2, no. 5, pp. 1-5, 2011.

[3] R. Dhankhar and A. Hooda, "Fungal biosorption - an alternative to meet the challenges of heavy metal pollution in aqueous solutions," Environ. Technol., vol. 32, no. 5, pp. 467-491, 2011.

[4] U. G. Anna Dzionek, Danuta Wojcieszyńska, "Natural carriers in bioremediation: A review," Electron. J. Biotechnol., vol. 23, pp. 28-36, 2016.

[5] P. Tittabutr, K. Teamthisong, B. Buranabanyat, and N. Teaumroong, "Gamma irradiation and autoclave sterilization peat and compost as the carrier for rhizobial inoculant production," $J$. Agric. Sci., vol. 4, no. 12, pp. 59-67, 2012.

[6] P. Taylor, D. D. D. Jr, J. Lee, J. Uknalis, A. A. Boateng, C. Ziegler-ulsh, D. D. D. Jr, J. Lee, and J. Uknalis, "Pelletized biochar as a carrier for AM fungi in the on- farm system of inoculum production in compost and vermiculite mixtures," Compost Sci. Util., vol. 22, pp. 253-262, 2014.

[7] Forum for Nuclear Cooperation in Asia (FNCA) Biofertilizer Project Group, Biofertilizer Manual. Tokyo: Japan Atomic Industrial Forum (JAIF), 2006.

[8] T. Retno and D. L. Nana, "Bioremediation of oil sludge contaminated soil using bulking agent mixture enriched consortia of microbial inoculants based by irradiated compost," J. Ilm. Apl. Isot. dan Radiasi, vol. 9, no. 2, pp. 139-150, 2013.

[9] Forum for Nuclear Cooperation in Asia (FNCA) Biofertilizer Project Group, Biofertilizer Manual. Tokyo: Japan Atomic Industrial Forum (JAIF), 2006.

[10] N. Pensupa, M. Jin, M. Kokolski, D. B. Archer, and C. Du, "A solid state fungal fermentation-based strategy for the hydrolysis of wheat straw," Bioresour. Technol., vol. 149, pp. 261-267, 2013.

[11] Ministry of Agriculture Republic of Indonesia, "Minimum Technical Requirements of Solid Organic Fertilizer. Regulation No.28/Permentan/SR.130/5/2009.” 2009.

[12] National Standardization Agency of Indonesia (Badan Standardisasi Nasional - BSN), "Specification of domestic organic garbage compost (SNI No. 19-7030-2004)." 2004.

[13] Minitab, "Minitab 16 statistical software." Minitab Inc., State College, Pennsylvania, 2010.

[14] D. A. A. El-fattah, W. E. Eweda, M. S. Zayed, and M. K. Hassanein, "Effect of carrier materials, sterilization method, and storage temperature on survival and biological activities of Azotobacter chroococcum inoculant," Ann. Agric. Sci., vol. 58, no. 2, pp. 111-118, 2013.

[15] K. Pakshirajan and T. Swaminathan, "Biosorption of copper and cadmium in packed bed columns with live immobilized fungal biomass of Phanerochaete chrysosporium," Appl Biochem Biotechnol, vol. 157, pp. 159-173, 2009.

[16] F. Y. Wang, H. Wang, and J. W. Ma, "Adsorption of cadmium (II) ions from aqueous solution by a new low-cost adsorbent Bamboo charcoal," J. Hazard. Mater., vol. 177, no. 1-3, pp. 300306, 2010. 